\title{
Assessing Development Paradigms of Democracy: A Perspective of Minimal Democracy in the Colony of the Cape of Good Hope 1853 - 1994
}

NDAGUBA, E.A.

\section{Abstract}

$T^{\mathrm{T}}$ is paper is a first of two separate papers in an attempt to recount the antecedent of minimalist democracy in the Colony of the Cape of Good Hope. The study uses thematic reviews, documentary evidence, scholarly encyclopaedia and articles. Other methods used in gathering data for the study include legislative proceedings, enactments and Acts, as well as various Constitutions and information from websites (www.nelsonmandela.org). The study establishes that there existed tenets of democratic element not in wholeness as with maximalist approach to democracy in the Cape of Good Hope. Nonetheless, based on the context of time and space. It contends that both representative and responsible democracy existed in practice and principle in the Cape of Good Hope between 1854 and 1872 respectively. The central thesis of this paper is that, the Colony of the Cape of Good Hope is arguably the first and only Colony under British Conquest in Africa to operate both representative and responsible government in colonial era. Also, opportunities were evenly shared between whites and non-whites. It concludes with an African Proverb that says, "Until lions tell their tale, the story of the hunt will always glorify the hunter."

Keywords: Democracy, Minimal Democracy, Cape of Good Hope, Colonial Era 
Assessing Development Paradigms of Democracy in the Colony of the Cape of Good Hope 441

\section{Introduction}

The notion of democracy by Abraham Lincoln (1809-1865) set the stage for traditional and medieval ideological foundation of minimal democracy. With the phrase that democracy, "government of the people, by the people, and for the people", crowned the parochial and classical underpinning of democracies. The idea of Lincoln can thus be summarized as representative and responsive governance structure and system in a state. Hence, such parochial assumptions and idiosyncrasies still resonate in democracy discourse regardless of its advancement in depth, principle, practice, and understanding.

To have a laconic comprehension of the depth of democracy, the paper will outline and interpret legislations, enactments, policies, and ordinances that corroborate in the argument that there existed even minimally in the British Colony of the Cape of Good Hope between 1853-1990. Premised on the notion, that democracies overtime have expressed itself in diverse facets and dimensions, forms and perspectives in human antiquities (representative, responsive, expansive democracies, etc.). Though, earlier forms of democracies and democratic liberalism were instituted to protect the rights and privileges of a few (see protective democracies). Been that, the form of democracy at the time was built to protect the bourgeoisie from the protectorate (capitalist from labourers). Arguably, ideals of universal suffrage, human rights, freedom, liberty, pluralism, socialism, political participation and citizen's engagement or involvement, and democratic accountability were non-existent.

Since there has been several documented evidence of democracy post-1994. The study lies on the weakness of the shortage/ deficiency in academic material on democracy prequel to 1994 . Hence, the need to investigate in order to ascertain whether their existed (minimally or maximally) tenets of democracy afore 1994, as well as to understand the shifts in various epochs in colonial history of democracy.

The need to ascertain the existence of democratic elements before 1994 is to reflect on past 'democratic' quagmires and achievements, which will enable a nation to measure or adjudge its achievements. As simplified in the words of Terry Pratchett (2010):

If you do not know where you come from, then you don't know where you are, and if you don't know where you are, then you don't 
know where you're going. And if you don't know where you're going, you're probably going wrong. ${ }^{1}$

Evidence shows that democracy was based on suffrage in the $19^{\text {th }}$ century (Worden, 2011: 171). Hence, election was persisted as the commonly used perceptions for underscoring democracy across board (though till date some nations still lie on this, see Zimbabwe and Cameroun) (Held, 2006: 1). However, this notion has gathered dust, as the US congresswoman Jeane Kirkpatrick puts it, "Democratic elections are not merely symbolic legislations or collective dimensions. They are competitive, periodic, inclusive, definitive elections in which the chief decision-makers in a government are selected by citizens who enjoy broad freedom to criticize government, to publish their criticism, and to present alternatives" (Mbi, 2007; Kirkpatrick, 1988). ${ }^{2}$ Hence, a nation whose democratic values does not subsume the aforementioned are vilified from been referred to as a democratic entity.

Recent advancement in democratic discourse resonate the idea that every system that practice democracy must hold in esteem, the place and supremacy of the constitution, respect of the constitutional provisions and loyalty to such provisions enacted or adopted by parliament, separation of powers among various arms and sphere of government, promotion of political pluralism, recognition of the roles and responsibility of opposition as a watchdog, in additional to a constitution that recognise fundamental rights in conformity with the Universal Declaration of Human Rights of 1948 and dichotomy of public administration from politics (Somalia Times, 2005; ${ }^{3}$ The Economist Intelligence Unit Limited 2016; Gyimah-Boadi, 2004; Bujra and Adejumobi, 2002) are quintessential ingredient towards democratic accountability. Nonetheless, for the purpose of this study and for the paper to portray as well as show that though full democratic principles might not be invoked. Conversely, it argues that democracy based on minimal democracy was feasible.

1 https://www.goodreads.com/quotes/412254-if-you-do-not-know-where-you-come-fromthen

${ }^{2}$ https://www.ait.org.tw/infousa/zhtw/DOCS/whatsdem/whatdm5.htm

${ }^{3} \mathrm{http}: / /$ www.somalilandtimes.net/sl/2005/204/26.shtml 
Assessing Development Paradigms of Democracy in the Colony of the Cape of Good Hope 443

\section{Minimalist approach}

The notion of Minimalist Democracy is ceded in Scherpeter's (1942) contraption of democracy. Where he argued, "democracy is a system, in which rulers are selected by competitive elections" (Przeworksi, 1999: 12). The idea was further corroborated by Poper (1962: 12), when he contends in similar vein, that democracy is the only system of government in which citizens holds the right to change a government without bloodshed (Przeworksi, 1999: 12). In Adam Przeworski defence on the concept of minimalist democracy summarizes its notion from both Popperian and Schumpeterian argument. That the concept of minimalist democracy is a description of value connotation where empirical evaluation is definitional. Characterized by representation, equality, participation, security, rationality, and justice among others. The clearest analogy in support of minimalist democracy is that "unless democracy is x or generates x..." Though there was no clarity as to the ellipses, therefore no conclusion can be empirically drawn. However, several scholars (Weffort, 1992; Schmitter and Karl, 1991; Shapiro, 1996: 108; Kelsen (1988 [1929]: 38) have argued that the statement is a reflect of either, "unless $x$ is fulfilled or that democracy in a minimal sense will not endure unless $x$ is satisfied" (Przeworski, 2001: 23-24). Which is in line with the first assertion of minimalist democracy by Scherpeter in this paper. That sees democracy as a system of transferring or transition of power through competitive election. As emphasized by Bobbio (1984: 156), that democracy is nothing other than "a set of rules... for the solution of conflict without bloodshed crowns the ideal of minimalist democracy.

Hence, the idea of democracy was view that enables for a transition of power in a peaceful manner. Thereby, the ballot was seen as the only available means through which such transition is possible without conflict or bloodshed. It can also be argued that the idea of minimalist democracy is centred on competitiveness. In that, Loser's in a certain competitive election can only wait for another tenure before they contest. Been the premise of the argument by Bidner, Francois, and Trebbi, (2015), that minimalist democracy is a transitory phase on the path towards fuller democracy; else a stable government practice in itself. In that, most developing countries (even in recent time) are often dependent on this notion of democracy.

To Morlino (2002), the idea of minimalist or maximalist approach to democracy is dependent on the degree of liberty and freedom it guarantees. Hence, a democracy is qualified as 'good' when it establishes a clear notion of quality. According to Morlino 
(1998), certain essential constituents constitutes that idea of a minimal democracy as, universal adult suffrage, recurring free, competitive and fair elections, more than a single political party, and where more than one source of information is guaranteed. However, predominantly in his argument that two major objectives are a proverbial of the degree of democracy even while minimal in any society. They include, equality and freedom.

Premised on the rational for minimalist democracy, the study will portray the existence of this form of democracy prequel to the amalgamation or the Union of South Africa by 1910. Thereby, dialyzing existing trajectories for suffrage from 1853 -1994 in the Cape of Good Hope and beyond.

\section{The Cape of Good Hope (1835 - 1910)}

Prequel to the amalgamation of the British Colonies to form the Union of South Africa in 1910, tenets of democracy (as suffrage and equality) was demonstrated in the British Colony of the Cape of Good Hope.

In 1835, Britain granted the Colony of the Cape of Good Hope Minimal Legislative Council without authority and power to enact laws, hence power and authority was residual with the Queen of England. Between 1835 and 1852, some political elite as John Molteno, Saul Solomon, John Fairbairn, William Porter, Jarvis, Hercules Crosse, Schreiner, William, and Stockenström among others agitated for local self-government. In 1853, after persistent struggles the Cape was granted representative government. Hence, the government though constituted by locals, the authority and power of the government to neither make nor implement decisions were vested on the British Crown.

Hence, by 1853 the first Parliament of the Cape of Good Hope (Legislative Council Upper house and Inaugural Assembly-Lower house) was elected without Executive Powers. Though the Colony had granted it permission to draft its own constitution as well as run a representative political system. One of the essential quality of the liberal document of the Cape, was that it prohibited class or race discrimination. In doing so, it instituted a non-racial Cape Qualified Franchise. In which same qualification for suffrage was administered to all males equally regardless of race (Cape Constitution of 1853; BickfordSmith, 2003:26). The Cape Qualified Franchise guarantees a system of government that is non-segregationist, non-separatist, and non-racist in nature. Which is in accordance with the 1853 Constitution of the Cape of Good Hope, that stipulates that to qualify for suffrage "All males living permanently within the colony that possessed property worth $£ 25$ were 
Assessing Development Paradigms of Democracy in the Colony of the Cape of Good Hope 445

permitted to vote, a vote which until 1887 did not take place under a secret ballot. The property qualification to be elected to the Legislative Council... was set at $£ 1,000$ in unencumbered property, while $£ 25$ was sufficient to be elected to the House of Assembly" (Crais, 1992: 192; Simons and Simons, 1969: 23). Which Worden (2011: 171), alluded that at that time, the existence of a voter's qualification was a standard feature of early democracies". Also the "£25 vote" was the lowest in the world for voters' qualification at the time.

After attaining representative government in 1853, in 1854, the bi-cameral legislature of the Cape of Good Hope was inaugurated as Legislative Council (Upper House) and Inaugural Assemble (Lower House) collectively called Parliament of the Cape. However, its loyalty was still to the Queen of England, since the Queen reserved the powers and authority in the appointment of the Prime Minister.

\section{A Trajectory of Qualification for suffrage in the Colony of the Cape of Good Hope}

The qualification for suffrage in the study is mainly limited to the Colony of the Cape of Good Hope. However, for a boarder understanding, this paper portrays the nature of events in other British Colonies in the areas now referred to as the Republic of South Africa.

As seen above, while the Colony of the Cape of Good Hope experienced to some extent equality, suffrage and freedom. However, in Natal, Orange Free State and Transvaal, discrimination as to suffrage against coloured and black African were gathering momentum. For instance, the Natal Exemption Law of 1865 and Natal Native Franchise Act No 28 of 1865 promulgation exclude all black Africans in Natal from voting. While in both Orange Free State and Transvaal only white had voting privileges.

In these colonies (Natal, Orange Free State, and Transvaal) there were high tendencies of discrimination against people of colour. Whereas, in the Colony of the Cape of Good Hope democratic institutions, systems and structures were being strengthened. In 1872, the Cape of Good Hope gained Responsible Government, ${ }^{4}$ which brought to a halt British

4 "Democratic politics and democratic administration give rise to government of responsibility. It refers a government that actively respond to, and attempt to meet the requests of the citizens. The government is then supposed to bear ethical, political, administrative and legal responsibilities. It also brings about a set of control mechanism over 
Supremacy in the Cape's activities. And introduced the three branches of the state's government under local control by the elected Governor. This action eventually made the Executive, democratically accountable to its local people other than the Britain. In 1874 and 1878, the new government of Thomas Upington continued to uphold the non-racial, non-separatist or white supremacist mantra. Affirming that both Black Africans and Coloured people be treated and availed same opportunity as with white counterpart in the Colony of the Cape of Good Hope.

However, democratic exclusion only permuted the Cape of Good Hope in 1890. When Cecil Rhodes assumed office as Prime Minister of the Cape of Good Hope. ${ }^{5}$ Before the emergence of Rhodes, the Cape system "allowed for any man with a minimum property ownership or $£ 25$ to vote." ${ }^{6}$ In the 1887 , Rhodes enacted a legislation that reduced the voting rights of non-white citizens by increasing the franchise qualification from $£ 25$ to $£ 75$, premised on his assumption that:

The native is to be treated as a child and denied the franchise. We must adopt a system of despotism, such as works in India, in our relations with the barbarism of South Africa (Magubane 1996: 108).

His notion or move, though not unconstitutional at the time, disenfranchised much of the Coloured and Black Africans voters, who were inadvertently poorer to the whites till date (see the table for the trajectory of poverty from 1910-1994) ${ }^{7}$ (Simons \& Simons 1969: 50). The Cape Franchise \& Ballot Act of 1892 raised the ballot franchise from $£ 25$ to $£ 75$ at the expense of black Africans and coloured. It is worth noting that while in other British Colonies as Transvaal, Orange Free State and Natal. The Glen Grey Act of 1894 set precedence for land grabbing in the Cape (Davenport, 1987: 181) with the implementation of the "one-man-one-plot" of land that shred and arrogated most agrarian farmlands to whites (this marked the beginning of extreme poverty in colonies especially for the blacks

the government". Cheng-fu, Z. 2000. On Responsible Government. Journal of Renmin University of China

${ }^{5} \mathrm{http}$ ://hsf.org.za/resource-centre/hsf-briefs/a-long-walk-to-univers...

${ }^{6} \mathrm{http}: / / \mathrm{hsf}$.org.za/resource-centre/hsf-briefs/a-long-walk-to-univers... 
(see Table on Racial Profile form 1911 - 2011) (Wolpe, 1972: 72). And subsequently, property ownership was waived as a criterion for suffrage among white males (Davenport, 1987: 108). ${ }^{8}$ Before the amalgamation of the Union of South Africa in 1910; the Cape of Good Hope had several Prime Ministers, who weighed both residual powers and authority, as well as been both locally responsible and accountable.

Figure 1: Trajectory of Poverty from 1911-1996

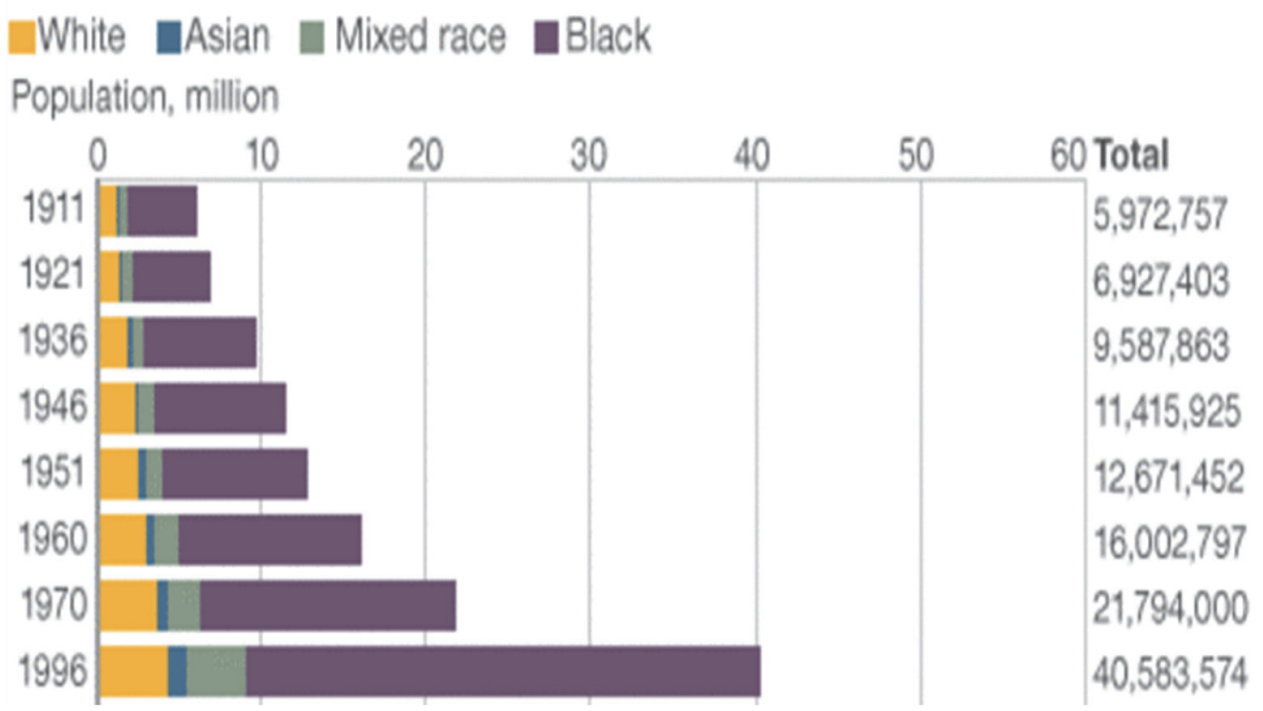

Source: StatsSA 2011.

\section{Democracy during Union of South Africa (1910-1948)}

According to Maho (2002: 15), the South Africa Act is the British Act of Union passed by the British Parliament at Westminster, wholly constructed by representative in South Africa (Allen, 1992: 193,196; Worden, 1994: 69; Christopher, 1994: 178). This document sets out the legal provisions for the Union of South Africa, which was proclaimed by 1910 (Maho, 2002: 15; Davenport, 1987: 247). As a democratic community the Union of South Africa (Henceforth the Union), established three arms of government: Administrative and

\footnotetext{
${ }^{8}$ Cape Parliamentary Registration Act of 1887
} 
Executive Head situated in Pretoria, the Parliament in the Cape, and the Appellate Division of the Supreme Court located at the Orange Free State (now Bloemfontein other names remains the same) (May, 1995: 145; Maho, 2002: 15).

The first parliament of the Union constitutes a bi-cameral legislature, with a House of Representatives (Lower House) consisting of 121 members, and the Senate (Upper House) consisting of 40 members, 8 from each province elected by "proportional representation and (the remaining) nominated by the Governor General, of whom 4 should have a thorough acquaintance... with the reasonable wants and wishes of the coloured races" (May, 1995: 145). The South African Act stipulates that whilst most of the provisions of the Union Act could be amended by a simple majority of each House. However, "for the section protecting the voting rights of the non-white people of the Cape (Section 35) ... and the section defining the equal status of the English and Dutch languages (Section 137) ... could only be amended by at two-thirds majority at the third reading in a joint session of both Houses" (Davenport 1987: 247; Section 152 of the South African Act, 1910). "These three sections came to be known as the entrenched clauses and were later to be the subject of a bitter constitutional dispute" (Dugard 1978: 27ff). ${ }^{9}$

According to Christopher (1994: 178), Section 151 of the Schedule of South Africa Act also made proviso for future inclusion of Bechuanaland, Basutoland, Southern Rhodesia, and Swaziland (Walker, 1962: 103) ${ }^{10}$ as part of the Union. After the amalgamation of the British Colonies in 1910, an effort by the Cape Province towards a multi-racial franchise was disdained (Maho, 2002:15). However, the Constitution permitted inclusive suffrage at the Cape Province after the amalgamation of the Union. At the First Union's elections, only $15 \%$ of black electorate was non-white in the Cape Province, as a result of the remodelling of suffrage qualification ( $£ 75$ and literacy level). While in the Orange Free State which shared similar characteristics with the Transvaal Region only white male over 21 years were allowed to vote (Maho, 2002). In Natal, 99\% of the electorate at Natal was white (as a result of the suffrage requirement of both property and literacy criteria).

\footnotetext{
${ }^{9}$ O'Malley, P

https://www.nelsonmandela.org/omalley/cis/omalley/OMalleyWeb/031v01538/04lv01646/0 5lv01735.htm

${ }^{10}$ Ibid. O’Malley, P
} 
In 1930, white women above the age of 21 were enfranchised through the Women's Enfranchisement Act of 1930 (Scully, 2000). ${ }^{11}$ In 1931 the Franchise Law Amendment Act qualified all white men and women for suffrage with qualifications. ${ }^{12}$ But in the Cape Province qualifications still applied to non-white votes, both in Natal and the Cape Province.

The qualification mantra of non-white and the removal of requirement of the whites ensued concerns with respect to discrimination. The discrimination was later legalized through the Representation of Native Act No. 16 of 1936, which removed all black Africans from the common roll, which they have been registered since 1854 in the Cape. The Act also stipulates that six white officials, twelve elected Africans and four nominated is allowable for block voting (Loveland, 1999; O'Malley, 1936) ${ }^{1314}$. It is based on the notion of elected representation of the twelve Africa that ZK Matthews made a submission about the Act. When he argued that the Act was established to deal:

With the problem of the political representation of Africans in the Union, the Act provided for the establishment of a Council consisting of partly nominated and partly elected African members whose function would be to advise the Government on legislation and other matters affecting African welfare ... (with hopes of establishing a) Native Parliament (Matthews, 1946). ${ }^{15}$

According to O'Malley, in addition to black Africans welfarism, the Act also established a Native Representative Council, with 6 white officials, 4 nominated and 12 elected Africans (Belnart, 1994: 118,132; Simons and Simons, 1969: 495). ${ }^{16}$ Several enactments preceded the Representation of Native Act No. 16 of 1936 premised on three assumptions, the fear

\footnotetext{
${ }^{11}$ Women's Enfranchisement Act, 1930

12 Franchise Law Amendment Act of 1931

${ }^{13} \mathrm{http}$ ///www.sahistory.org.za/dated-event/representation-natives-act-passed

${ }^{14} \mathrm{http}$ ://global.britannica.com/topic/Representation-of-Natives-Act

15 An article published in November 1946 by the revered scholar Professor ZK Matthews, which gave a chronicle of the expectations (the rise, the ugly and the fall) of the Representation of Native Act No. 12 of 1936, which established the Native Representative Council in 1937.

${ }^{16} \mathrm{https}$ ://www.nelsonmandela.org/omalley/index.php/site/q/031v01538/041v01646/05lv017 83.htm
} 
of rebellion, housing and urban settlement, and thirdly the capitalist ideology of accumulation, such Acts as, War Measure No. 1425 of 1945, at the rise of the Second World War. The Act prohibited the gathering of more than twenty people in mining for fear of rebellion. The Housing Emergency Power Act of 1945, enacted at the hills of growing concern for housing for both Whites and non-White peoples. The Act "authorized public authorities to expropriate land and materials, build houses and conscript workers" (Simons and Simons, 1969: 561). The Native Urban Areas Consolidation Act No. 25 of 1945 and the Native Laws Amendment Act, 1945 are arguably referred to as, Bantu Urban Areas Consolidation Act (Dugard, 1978: 22; Crush, et al. 1991:146; Dyzenhaus, 1991: 37). Which according to Fine and Davis (1990: 76), the major essence of the Act, was to "tightened influx control" in urban centres, which is largely a follow-up to Native Urban Areas Act of 1923 and other Native Enactment concur to these assumptions, that later formed the basis for segregation.

\section{Democracy during Apartheid Era (1948-1994)}

These Native Laws and several amendments and enactment as the Cape Franchise and Ballot Act of 1892, Reformed Act of 1884, Cape Parliamentary Registration Act of 1887, Orange Free State Statute Book Act, Natal Native Code of 1891, Native Locations Act of 1879, Trade in Diamonds Consolidation Act of 1882, Kaffir Employment Act No. 27 of 1857, Natal Exemption Law of 1865, Natal Native Franchise No. 28 of 1865, Glen Grey Act of 1894, Natal Franchise Act of 1896, Native Reserve Locations Act No. 40 of 1902, Natal Native Locations Act of 1904, Native Land Act No. 27 of 1913, Native Affairs Act No. 23 of 1920, Native Urban Areas Act No. 21 of 1923, Masters \& Servants Amendment Act of 1926, Transvaal Asiatic Land Tenure Act No. 35 of 1932, Slums Act of 1934, Representation of Natives Act No. 12 of 1936, Natives Laws Amendment Act of 1937, War Measures Act No. 13 of 1940, War Measure No. 1425 of 1945, Housing Emergency Powers Act of 1945, Native Urban Areas Consolidation Act No. 25 of 1945, and the Natives Laws Amendment Act of 1945 paved way for a separatist government of a "significant few". Which introduced Asiatic Law Amendment Act No. 47 of 1948, Prohibition of Mixed Marriages Act No. 55 of 1949, Natives Laws Amendment Act of 1949, South African Citizenship Act of 1949, Immorality Amendment Act No. 21 of 1950, Group Areas Act No. 41 of 1950, Suppression of Communism Act No. 44 of 1950, and Native Building Workers Act No. 27 of 1951 (Thompson, 1990: 194; Worden, 1994: 86; Christopher, 1994: 105; 1992: 406-407, 429; 
Assessing Development Paradigms of Democracy in the Colony of the Cape of Good Hope 451

Dugard, 1978: 100; Dyzenhaus, 1991: 79; Beinart, 1994: 146; Nattrass, 1993: 48; Simons and

Simons, 1969: 604; Dyzenhaus, 1990: 20; Price, 1991: 20; Lapping, 1986: 168; Davenport, 1987: 368; Riley, 1991) led to the infamous Separate Representation of Voters Act No. 46 of 1951 (Fine and Davis, 1990: 107f; Davenport, 1987: 364ff, Lapping 1986: 144f; Riley 1991: 25).

\section{Unpacking the Idealism of Native Laws cum Apartheid Legislation}

The idea in the implementation of apartheid began exclusively in 1948, when the National Party emerged as its frontrunner in South Africa. It implemented separatist ideologies known as apartheid. Under this notion, whites and non-whites were not meant to interact or have a relationship. ${ }^{17}$ Recreational facilities and utilities were built for whites and nonwhite population separately.

The separatist tendencies were heightened at the awake of International Sanctions, Depression and World War II. Leading to further demarcation and separation that divided the population by colour, ${ }^{18}$ therefore the classification of the South African population into four, Bantu (Black), white, and Coloured (mixed race) and later Asians [Indian and Pakistan]. ${ }^{19}$

However, contestations exist among colonial and apartheid scholars as to the dialysis, signs and symptoms of apartheid and apartheid movement over the cause of history; in a bid to avert such tendencies in the nearest morai. In an argument in Maho (2002), in line with the confusion to the genesis or foundation of Apartheid and the genealogy of the policy that framed apartheid system:

According to Bonner et al. (1993) the idea of apartheid resonates or is in associate with Section 10 of the NATIVES URBAN AREAS CONSOLIDATION ACT of 1945 (Nattrass 1993: 47; Posel 1993: 414), which they argued as the basis and true origin of apartheid laws. For Crush et al. (1991: 146) "Section 10 entitlements" with the NATIVES LAWS AMENDMENT ACT of 1945 would probably be a misnomer, taking into

${ }^{17}$ See Immorality Act No 5, 1927, Immorality Amendment Act No 21, 1950, Prohibition of Mixed Marriages Act No 55, 1949

${ }^{18}$ See Population Registration Act, 1950

19 This law separated families, Coloured from whites' families viz-a-viz 
cognizance the nature of native restructuring and demarcation before 1945. Price (1991: 20, and elsewhere) further the argument that Section 10 should be the basis for apartheid policies, since it was included in the GROUP AREAS ACT of 1950. Davenport (1987) associates Section 10 with the NATIVES LAWS AMENDMENT ACT of 1952 on page 373 but with some unspecified amendment act (but not the same) on page 549 (possibly the NATIVES URBAN AREAS AMENDMENT ACT of 1952); Horowitz (1991: 11) seems likewise to associate it with NATIVES LAWS AMENDMENT ACT of 1952; and Worden (1994: 98+108) refers to it as part of the NATIVES URBAN AREAS AMENDMENT ACT of 1955.

While authors views of the genesis of apartheid law remained problematique, this study argues that the notion which later resulted in some separatist legislations in 1945, 1950, 1951, 1952, and 1955 are merely a build up from the 1913 promulgation of the Land Act, which coerced most black Africans to reside in reserves, enacted barely three years into the Union of South Africa.

\section{Finding of the study}

1) The study establishes that there existed tenets of democratic element not in wholeness as with maximalist approach to democracy in the British Colony of the Cape of Good Hope. Nonetheless, based on the context of time and space. It study contends that both representative and responsible democracy existed in practice and principle in the British Colony of the Cape of Good Hope between 1854 and 1872 respectively. Therefore, lessons should be learnt on how administration was carried out during this period. In order to further enable current policy maker to avert same mistake which disintegrated the society on the one hand, and pushed several millions of individuals and families below the poverty level.

2) The central thesis of this paper is that the British Colony of the Cape of Good Hope can be arguably referred to as the first and only Colony under British Conquest to both operates representative and responsible government in colonial era. 
3) That in the British Colony of the Cape of Good Hope, opportunities were evenly shared between whites and non-whites ${ }^{20}$ (to some degree), affirmed by the Supreme Law of 1853 is an essential tenets of minimalist democracy. Hence, even before the 1945 ballot in America, black citizens of the Colony of Good Hope had enjoyed partially fairness and equality as against all other Colony and black people around the world. Hence further inquiry should be conducted to reason behind The Cape partial inclusive democracy.

4) The study argues the place of public policy in either destruction or development. While minimalist democracy was enjoyed in the Cape, Transvaal and Natal experience severe authoritative system of exclusion. Which could be one of the reasons why even blacks in The Cape tend to be much Enlighten in academic and others as compared to other. As a result, with their rapport with Europeans and merchants.

5) Also the study reveals that during the period under review, suffrage was premised on ownership of property worth $£ 25$, which was later increased to $£ 75$ with literacy under John Cecil Rhodes in 1890s (who later became the pioneer for the apartheid movement). At the time, across the world the determinant for suffrage was property, and the amount for the Cape of Good Hope was the Cheapest. However, this idea is argued as a means towards disenfranchising or excluding most blacks who were not educated and/ or poor.

6) Women were enfranchised as far as 1930 (Scully, 2000). Through the Women's Enfranchisement Act, 1930, which enabled women above 21 to vote without qualification. Hence the analysis by http://www.infoplease.com/ipa/A0931343.html among others must be disregarded at the wake of this reality. Which shows that women were only allowed to vote in the Union of South Africa in 1994.

\section{Conclusion}

Despite the despotic nature and minimalist approach to democracy as expunged in this study, it must be noted that laws where functional, though rights and privileges were abused, the court was independent. Hence, the executive provided services for enclaves they deem fit for such service. Though, principles of neutrality, equality or equity were

${ }^{20}$ Mainly in terms of suffrage 
non-existent in addressing the nations woes. However, it was arguably democratic, democratic in the popular notion of minimal approach to democracy as ceded in Lincoln's definition, "for the people, by the people and of the people". The idea then was that the white supremacist never considered non-whites as fellow citizens rather as sojourners.

The central idea for the demarcation was primarily for administrative convenience, ceded in the colonial heritage of divide and rule. ${ }^{21}$ The situation and management of the agenda went sour when the idea of private ownership and accumulation in the notion of capitalism gathered momentum (Rosser, and Barkley, 2003; Zimbalist, and Brown, Howard and Stuart, 1988; Jenks, 1899). ${ }^{22}$ Capitalism which is characterized by capital accumulation, voluntary exchange, private property, price system, investment, land, and the production of capital and financial markets (Gregory and Stuart, 2013; Heilbroner, 2008; Hyman and Baptist, 2014). ${ }^{23}$ All enabled the bourgeoisie to use freely labourer without paying for such labour.

The fusion of the notion of capitalism and democracy is referred to as democratic capitalism. Which Novak and Benne in separate studies argues as:

...a political, economic and social ideology that involves the combination of a democratic political system with a capitalist economic system. It is based on a tripartite arrangement of a private sector-driven market economy based predominantly on a democratic policy, economic incentives through free markets, fiscal responsibility and a liberal moral-

\footnotetext{
${ }^{21}$ See also the balkanization of Africa

22 Jenks, C. "Capitalism, as a mode of production, is an economic system of manufacture and exchange which is geared toward the production and sale of commodities within a market for profit, where the manufacture of commodities consists of the use of the formally free labour of workers in exchange for a wage to create commodities in which the manufacturer extracts surplus value from the labour of the workers in terms of the difference between the wages paid to the worker and the value of the commodity produced by him/her to generate that profit." While in Rosser, M. V. and Barkley, J. Jr. 2003. "In capitalist economies, land and produced means of production (the capital stock) are owned by private individuals or groups of private individuals organized as firms."
}

${ }^{23}$ Merriam Webster, Capitalism. From http://www.merriamwebster.com/dictionary/capitalism 
cultural system which encourages pluralism (Benne, 1981; Novak, M.

1982)

In conclusion, this paper offers a sketch of minimalist democracy in the British Colony of the Colony of Good Hope and the Union of South Africa. The sketch is neither to theorise nor to propose a new knowledge or way of thinking. Rather to show that there existed tenets of democratic embryo in the region of the Colony of Good Hope and the Union of South Africa. However, commonalities exist between the Colony of Good Hope and the Union of South Africa to a large extent. Whereas, in the Colony of Good Hope enjoyed some level of equality and rights. Regions such as Transvaal, Natal and Orange Free State were largely discriminated against right before separatism. Finally, the argument recounted in this paper is one of many that tend to tell the African story from an African perspective. Because an African Proverb once said, "Until lions tell their tale, the story of the hunt will always glorify the hunter."

\section{List of References}

- $\quad$ Adams, I. 2001. Political Ideology Today. Manchester: Manchester University Press.

- $\quad$ Ake, C. 1993. The Unique Case of African Democracy. International Affairs (Royal Institute of International Affairs 1944-) Vol. 69, No. 2 (Apr., 1993), pp. 239-244.

- Bidner, C. Francois, P. and Trebbi, F. 2015. A Theory of Minimalist Democracy.

- Beall, Jo and Gelb, Stephen and Hassim, Shireen (2005) Fragile stability: state and society in democratic South Africa. Journal of Southern African studies, 31 (4). pp. 681-700 DOI: 10.1080/03057070500370415.

- Benne, R. 1981, The Ethic of Democratic Capitalism: A Moral Reassessment, Philadelphia: Fortress Press, ISBN 0-8006-1445-3

- Bickford-Smith, Ivian. 2003. Ethnic Pride and Racial Prejudice in Victorian Cape Town Cambridge University Press. 2003. p.26

- Brown, W. 2005. Edgework: Critical Essays on Knowledge and Politics. Princeton University Press, 2005. p. 39 
- Crais, C. C. 1992. White Supremacy and Black Resistance in Pre-industrial South Africa: The Making of the Colonial Order in the Eastern Cape, 1770-1865. Cambridge. Press Syndicate of the University of Cambridge

- Jelmin, K. 2012. Democratic Accountability in Service Delivery: A Synthesis of Case Studies. International Institute for Democracy and Electoral Assistance

- Jenks, C. Core Sociological Dichotomies. London, England, UK; Thousand Oaks, California, USA; New Delhi, India. SAGE. P. 383.

- Held, D. 2006. Models of Democracy. Third Edition. Cambridge. Polity Press.

- Kirkpatrick, J. J. 1988. Legitimacy and Force: Political and Moral Dimensions (Vol. 1). New Brunswick. Reansction Books

- Krugman, P. 1993. "The Narrow and Broad Arguments for Free Trade», American Economic Review, Papers and Proceedings, 83(3), 1993; and P. Krugman, Peddling Prosperity: Economic Sense and Nonsense in the Age of Diminished Expectations, New York, W.W. Norton \& Company, 1994.

- Loveland, I. 1999. By Due Process of Law: Racial Discrimination and the Right to Vote in South Africa 1855-1960. Hart Publishing. pp. 197-202. ISBN 978-0-313-29879-0.

- $\quad$ "Lodge de Goede Hoop and the Cape House of Assembly | Grand Lodge of South Africa Southern Division," Freemasonrysd.co.za.

- Matthews, Z. K. 1946. 'The Failure of the Natives' representative council', Pamphlet. South African History Online

- Mbi, J. T. 2007. A Brief Overview of the Meaning of Democratic Elections. Cameroon Journal on Democracy and Human Rights. CJDHR Vol. 1 No. 1 - June 2007

- Molteno, P. A. The life and times of Sir John Charles Molteno, K. C. M. G., First Premier of Cape Colony, Comprising a History of Representative Institutions and Responsible Government at the Cape. London: Smith, Elder \& Co. 1900

- Morlino, L. 2004. "What is a 'good' democracy?" Democratization 11, no. 5: 10-32.

- Morlino, L. 1998. Democracy Between Consolidation and Crisis. Parties, Groups and Citizens in Southern Europe, Oxford, Oxford University Press.

- Nattrass, N. 2014. South Africa: Post-Apartheid Democracy and Growth. Democracy Works/ Conference Paper. 
Assessing Development Paradigms of Democracy in the Colony of the Cape of Good Hope 457

- Novak, M. 1982, The Spirit of Democratic Capitalism, New York: Simon and Schuster, ISBN $0-671-43154-4$

- O'Malley, P. 2016. Racial Legislation 1806-1947. Nelson Mandela Centre of Memory. Nelson Mandela Centre of Memory site. From https://www.nelsonmandela.org/omalley/index.php/site/q/03lv01538/04lv01646.htm

- O'Malley, P. 2016. 1853. Cape Constitution. Nelson Mandela Centre of Memory. Nelson Mandela Centre of Memory site. From https://www.nelsonmandela.org/omalley/index.php/site/q/03lv01538/04lv01646/05lv01671. htm

- O'Malley, P. 1936. Representation of Natives Act No 12, from Nelson Mandela Centre for Memory, [online], Available at www.nelsonmandela.org [Accessed: 02 April 2014] - See more at: http://www.sahistory.org.za/dated-event/representation-natives-actpassed\#sthash.wTi1yWUw.dpuf

- Przeworski, A. Minimalist Conception of Democracy: A Defense. In Shapiro, I. and HackerCordsn, C. 1. 2001. Democracy's Values. (eds.). Cambridge. Cambridge University Press.

- Przeworksi, A. 1991. Democracy and Economic Development. In Mansfield E. D. and Sisson, R. Political Science and the Public Interest. (eds.). Columbus: Ohio State University Press

- Scully, Pamela (2000). "White maternity and black infancy: The rhetoric of race in the South African women's suffrage movement, 1895-1930". In Fletcher, Ian Christopher; Mayhall, Laura E. Nym; Levine, Philippa. Women's Suffrage in the British Empire: Citizenship, nation and race. London: Routledge. pp. 68-84. ISBN 041520805X

- Rosser, M. V. and Barkley, J. Jr. 2003. Comparative Economics in a Transforming World Economy. MIT Press. p. 7. ISBN 978-0262182348.

- The Economist Intelligence Unit. 2016. Democracy Index 2015 Democracy in an age of anxiety. The Economist. From http://www.isie.tn/wpcontent/uploads/2016/01/Economist_Intelligence_Unit-Democracy-Index-2015.pdf

- Walker, E. A. 1962. Reviewed Work: The Unification of South Africa, 1902-1910 by L. M. Thompson. The Historical Journal. Vol. 5, No. 1 (1962), pp. 102-104

- Worden, N. 2011. Cape Town: The Making of a City. New Africa Books. p 171.

- Xinhua, 2012. "Trade-oriented Economy Boosts Growth, Employment". CRI English. Retrieved 26 May 2012 (2012-05-24). 
- Zimbalist, S. and Brown, A. Howard J. and Stuart, 1988. Comparing Economic Systems: A Political-Economic Approach. Harcourt College Pub. pp. 6-7. ISBN 978-0155124035.

- http://www.capetown.at/heritage/history/british.htm 6.

- https://archive.org/stream/oldcapehousebein00kilpiala/oldcapehousebein00kilpiala_djvu.txt

\section{AUTHOR'S CONTACT:}

NDAGUBA, E.A.

School of Government and Public Administration University of Fort Hare

Email: endaguba@gmail.com 